\title{
Life and works of Gilles de la Tourette (1857-1904)
}

\author{
Saliha Seda Adanır ${ }^{1}$ (D) IIlhan Bahşi $^{1}$
}

Received: 18 July 2019 / Accepted: 28 July 2019 / Published online: 7 August 2019

(C) Springer-Verlag GmbH Germany, part of Springer Nature 2019

Georges Albert Edward Brutus Gilles de la Tourette (Figure 1 and Cover) was born on October 30, 1857, in Saint Gervais les Trois Clochers, a small town near Loudun in western France. His father, Theodore, was a merchant and came from a family of doctors [1-3]. Little is known about Tourette's early childhood. He began his education at the Chatellerault boarding school, where he drew attention with his extraordinary talents. In 1886, he married his cousin Marie Detrois and he had two daughters and two boys [2].

Tourette began medical school in Poitiers at the age of 16 and successfully completed his studies in 1881. In 1884, he began working at Salpetriere Hospital under Jean Martin Charcot (1825-1893), known as the one of the first physicians in the history of neurology and neuropsychiatry $[1,2]$. He quickly became one of Charcot's favorite students, and in 2 years he was promoted to Chef de Clinique [1]. At that time, Salpetriere Hospital was a research hospital working on hysteria and hypnosis. Tourette was interested in hysteresis, but mainly focused on neuropsychiatric disorders and neuropathology. He has published several scientific studies on epilepsia, neurasthenia, and syphilitic myelitis [2]. He published several articles on Charcot and his theories and a three-volume work called Traité clinique et thérapeutique de l'hystérie, d'après l'enseignement de la Salpêtrière (1891) (Fig. 2). In 1886, he was honored for his medical thesis on the method of finding a neurological diagnosis by foot form and footprints of patients, and the following year he received the Godard Prize [2]. In his book Hypnotism and similar states from the forensic point of view published in 1887 , he described two hysteria patients [3].

Saliha Seda Adanır

seda.adnr93@gmail.com

İlhan Bahși

dr.ilhanbahsi@gmail.com

1 Department of Anatomy, Faculty of Medicine, Gaziantep University, TR-27310 Gaziantep, Turkey
Because of his melancholy and unreal delusions, he had to leave his job in the hospital in 1901. These symptoms and the corresponding neurological findings were attributed to paretic neurosyphilis. He was hospitalized to the Cery psychiatric hospital near Lausanne, Switzerland. Over the next three years, he became increasingly psychotic and suffered from epileptic seizures. He died on March 22, 1904 and was buried in the family cemetery in Loudun $[2,3]$.

\section{Tourette syndrome}

French Doctor Jean Marc Gaspard Itard (1774-1838) described the behavior of Marquise de Dampierre in 1825 , which attracted everyone's attention by making body movements and strange sounds [4]. Sixty years later, in 1885, at the Archives de Neurologie, Tourette published a study on a nervous system disorder characterized by motor coordination (Étude sur une affection nerveuse caractèrisÉe par de l'incoordination motrice accompagnÉe d'Écholalie et de coprolalie) [2]. In this work, Tourette described Marquise de Dampierre's disease and eight similar cases, describing this neurological disorder as Maladie des Tics [2, 5]. Krämer and Daniels [2] reported that it was Tourette who first described Maladie des Tics. His mentor Charcot chose this eponym for the diseases because the name Tourette sounded lovely [2].

\section{Conclusion}

Krämer and Daniels [2] stated that Tourette did not make significant progress in his career because of ignoring issues outside his area of interest despite Charcot's support and his numerous works. However, it should be appreciated for its important contribution to neuropsychiatry and neuropathology. 


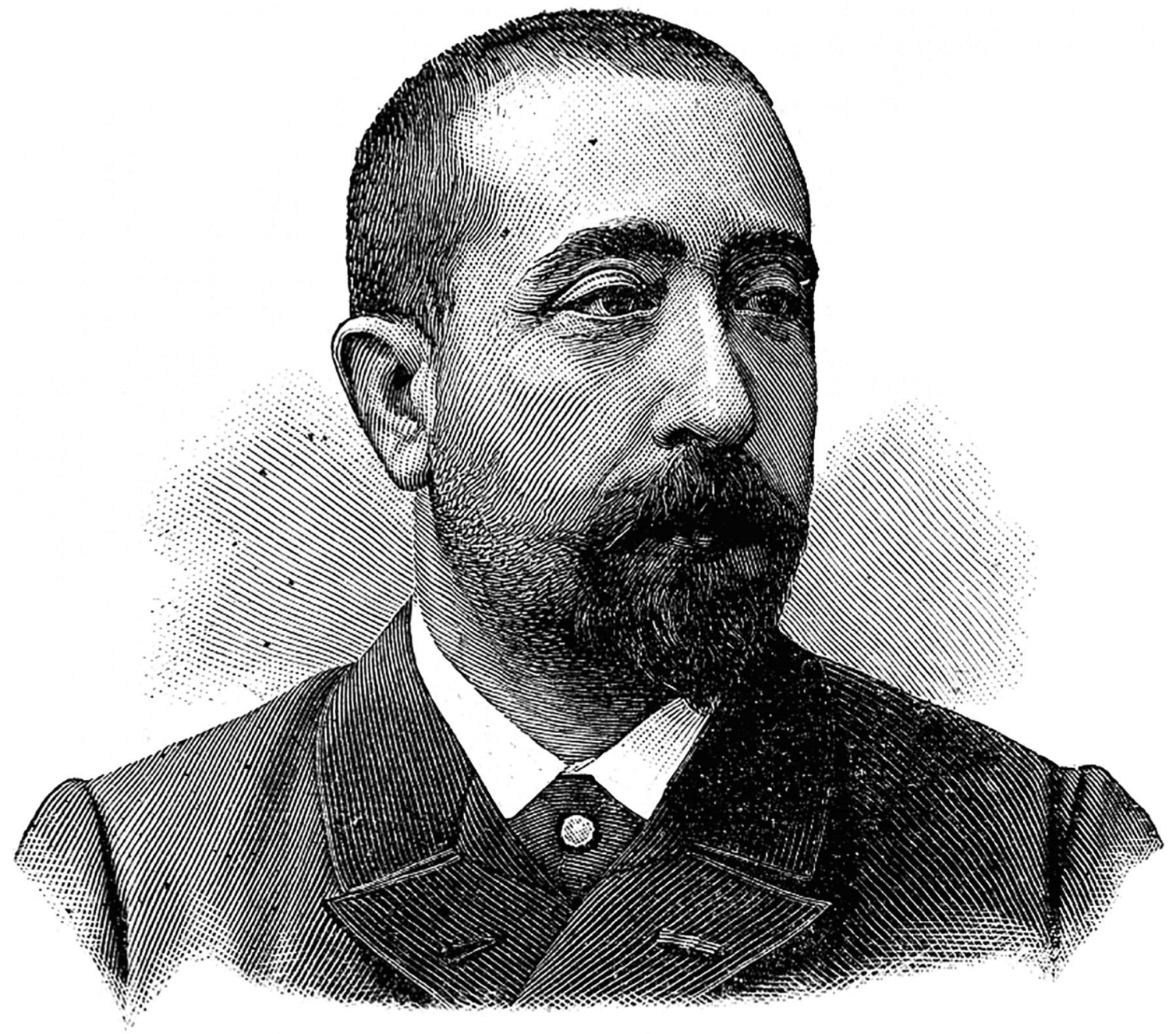

Fig. 1 and Cover Georges Albert Edward Brutus Gilles de la Tourette, which can be found at https://en.wikipedia.org/wiki/Georges_Gilles_de_la_ Tourette. Accessed 16 July 2019 
Fig. 2 Title page of Tourette's book is named Traité clinique et thérapeutique de l'hystérie, d'après l'enseignement de la Salpêtrière

\section{Compliance with ethical standards}

Conflict of interest The authors declared no potential conflicts of interest with respect to the research, authorship, and/or publication of this article.

\section{TRAITÉ}

CLINIQUE ET THÉRAPEUTIQUE

\section{DE L'HYSTÉRIE}

D'A P R È S

L'ENSEIGNEMENT DE LA SALPÊTRIÈRE

PA R LE DOGTEUR

\section{GILLES DE LA TOURETTE}

PROFESSEUR AGRÉgé A LA FACULTE DE MÉDECINE DE PARIS MÉDECIN DES HOPITAUX

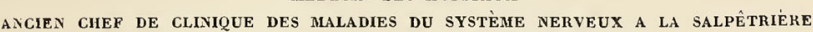
aNCIEN PRÉparateUR dU COURS DE MÉDECINE LÉGaLE

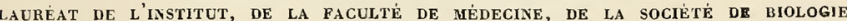
ET DE L'ACADEMMIE FRANCAISE

PRÉFACE DE M. LE $\mathrm{P}^{\mathrm{r}}$ J.-M. GHARGOT

* En une seule chose ne céderay-je à personne. en la recherche de la vérité. .

Théophraste Revaudot.

SEGONDE PARTIE

\section{HYSTÉRIE PAROXYSTIQUE}

avec 63 figures dans le texte

et un portrait à l'eau-forte du professeur Gharcot

I

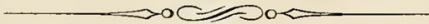

\section{PARIS}

LIBRAIRIE PLON

E. PLON, NOURRIT et $C_{i}^{\text {ie }}$ IMPRIMEURS-ÉdITEURS

RUE GARANCIÉRE, 10

895

Tous droits resservés

\section{References}

1. Walusinski O, Bogousslavsky J (2011) Georges Gilles de la Tourette (1857-1904). J Neurol 258(1):166-167. https://doi.org/10.1007/ s00415-010-5800-4 
2. Krämer H, Daniels C (2004) Pioneers of movement disorders: Georges Gilles de la Tourette. J Neural Transm (Vienna) 111(6): 691-701

3. Walusinski O, Duncan G (2010) Living his writings: the example of neurologist G. Gilles de la Tourette. Mov Disord 25(14):2290-2295. https://doi.org/10.1002/mds.23205

4. Itard JM (1825) Mémoire sur quelques fonctions involontaires des appareils de la locomotion, de la préhension et de la voix. Arch Gen Med 8:385-407
5. Lanska DJ (2009) The history of movement disorders. Clin Neurol 95:501-546. https://doi.org/10.1016/S0072-9752(08)02133-7

Publisher's note Springer Nature remains neutral with regard to jurisdictional claims in published maps and institutional affiliations. 